\title{
From the allocation debate to a substitution paradox in waste bioenergy life cycle assessment studies
}

\author{
Georgios Archimidis Tsalidis ${ }^{1}$ (D) - Gijsbert Korevaar ${ }^{1}$
}

Received: 12 June 2019 / Accepted: 13 August 2019/Published online: 26 August 2019

(C) The Author(s) 2019

\section{Climate goals and application of substitution}

Bioenergy will play a critical role in climate change mitigation. There are however several bottlenecks regarding the assessment of sustainability and efficiency of bioenergy systems, especially for first-generation biomass (e.g. sugars and vegetable oils) (Chakravorty et al. 2009; European Commission 2010; Popp et al. 2014). The use of secondgeneration biomass (e.g. lignocellulosic biomass, agricultural residues) as a sustainable energy source has therefore gained increased attention by researchers and decision-makers (Pandiyan et al. 2019). The Intergovernmental Panel on Climate Change (IPCC) has stressed the use of second- and third-generation biomass (with and without carbon capture and storage) for attaining the $1.5^{\circ} \mathrm{C}$ target of the Paris Agreement (IPCC 2018). Not surprisingly, the need for better understanding the environmental performance and trade-offs of large-scale biomass deployment has resulted in an increasing number of environmental assessment studies, mostly using environmental life cycle assessment (ELCA). One of the most enduring debates within the ELCA community is on handling multifunctional processes, which is a key feature of most bio-based processes. Here, we refrain from further dwelling on this discussion, but rather focus on discussing a specific approach to handling allocation and when it is used: the substitution method. In this discussion paper, we argue that the application of substitution in waste treatment

Responsible editor: Mary Ann Curran

Georgios Archimidis Tsalidis

g.a.tsalidis@tudelft.nl

1 Engineering Systems and Services Department, Faculty of Technology, Policy and Management, Delft University of Technology, Jaffalaan 5, 2628 BX Delft, The Netherlands processes in consequential ELCA has led to an overestimation of greenhouse gas (GHG) emissions due to avoided emissions.

Even though ELCA was developed a long time ago and has been standardized by ISO 14040 and 14044 (International Organization for Standardization (ISO) 2006a, b), differences in results among studies are often due to the interpretation of the guidelines. This happens because the standardization of ELCA concerns only its structure and ELCA is an assessment tool which is used for a wide range of product systems. Therefore, frameworks are continuously being developed on key points of the goal and scope definition phase, such as how to handle multifunctional processes (Guinee 2002).

Two main approaches exist in ELCA: attributional and consequential. According to the UNEP and SETAC (UNEP and SETAC 2011), attributional ELCA is defined as the portion of global environmental burdens that can be associated with a product's life cycle. Thus, it refers to a "static" or "steady state" system, a system fully integrated in a production-consumption system (Heijungs 1997; Sandén and Karlström 2007; Brander and Wylie 2011). Whereas, the consequential approach is defined as how physical flows and, consequently, environmental burdens will change in response to a change in the system under study (Finnveden et al. 2009).

Handling multifunctionality is one of the most debated methodological choices in ELCA (Majeau-Bettez et al. 2018). Multifunctional processes consist of co-production, waste treatment and recycling. Multifunctionality is typically handled with partitioning, system expansion or substitution methods, with each method leading to different ELCA results. The ELCA literature links partition-based co-production modelling with attributional analysis, and substitution based modelling with consequential analysis (Zamagni et al. 2012; Pelletier et al. 2015; Schrijvers et al. 2016). Partitioning is linked with attributional ELCA since no activity has changed in the system under study (Heijungs and Guinée 2007). On the other hand, 
substitution is linked with consequential ELCA as making a change in the initial system results in disrupting the original production-consumption system (Majeau-Bettez et al. 2018). Last, system expansion is linked to both approaches.

The ILCD handbook (Wolf et al. 2010) introduces approaches in solving multifunctionality based on the ISO 14044 (International Organization for Standardization (ISO) 2006b) hierarchy. However, in the ILCD handbook, substitution is treated as a form of system expansion, even though ISO 14044 does not refer to substitution (see ISO 2006b, p.76). Consequently, as ISO 14044 prioritizes system expansion over partitioning, substitution is also preferred in the ILCD handbook. Nevertheless, the ILCD handbook warns: "substitution can lead to negative elementary flows or in rare cases even negative overall environmental impacts of the analysed systems" (Wolf et al. 2010, p. 93).

The incorrect application of substitution in attributional ELCA from a theoretical perspective has been discussed by Brander and Wylie (Brander and Wylie 2011). Here, we focus on the impact of substitution method in global warming potential for consequential ELCAs of waste bioenergy systems. In this discussion paper, first, we introduce how the substitution method is applied. Second, we present how practitioners applied substitution in waste bioenergy studies and what the reasoning behind the choice was. Third, we discuss and quantify the impact of this decision in consequential ELCA results.

\section{Methodology}

In order to understand how practitioners applied substitution in waste bioenergy studies, a comprehensive review of scientific literature was performed for the period 2010-2018 in international peer-reviewed journals. The term "avoided emissions" in combination with the terms "bioenergy" and "life cycle assessment" were searched in the title, abstract and keywords of publications in the Scopus website. The focus of this study was on the use of substitution in waste treatments of waste bioenergy systems, and therefore ELCA studies that performed substitution in co-production processes were omitted and are not presented here. GHG emissions have been selected as a key indicator, as they are the predominant driver for European energy policy (European Commission 2009). The selected literature was reviewed based on two key questions:

1. How is the substitution method applied in waste treatment processes in waste bioenergy studies?

2. What is the impact of applying the substitution method in waste treatment processes in waste bioenergy studies?

\section{Substitution method and its application in waste bioenergy studies}

In this method, all secondary co-products of a multifunctional process are accounted for and considered as alternatives to primary products with the same functionality on the global market. The co-production is resolved by assuming that secondary co-products displace some other primary production of a different LCA system (Majeau-Bettez et al. 2018). This is performed by assessing the environmental performance of each primary product and incorporating the results in the ELCA system as avoided emissions. In other words, the system claims credits for emissions that were not produced but would have been produced if the system under study would not have been implemented, thereby adding an inventory to the product system which would have been viewed as external in the first place (Koffler and Finkbeiner 2018). An adapted scheme of applying substitution in multifunctional processes, as presented in the ISO (International Organization for Standardization (ISO) 2006b), is illustrated in Fig. 1. In this example, the investigated multifunctional process produces
Fig. 1 Substitution method principle based on ISO (International Organization for Standardization (ISO) 2006b) applied in bio-butanol production
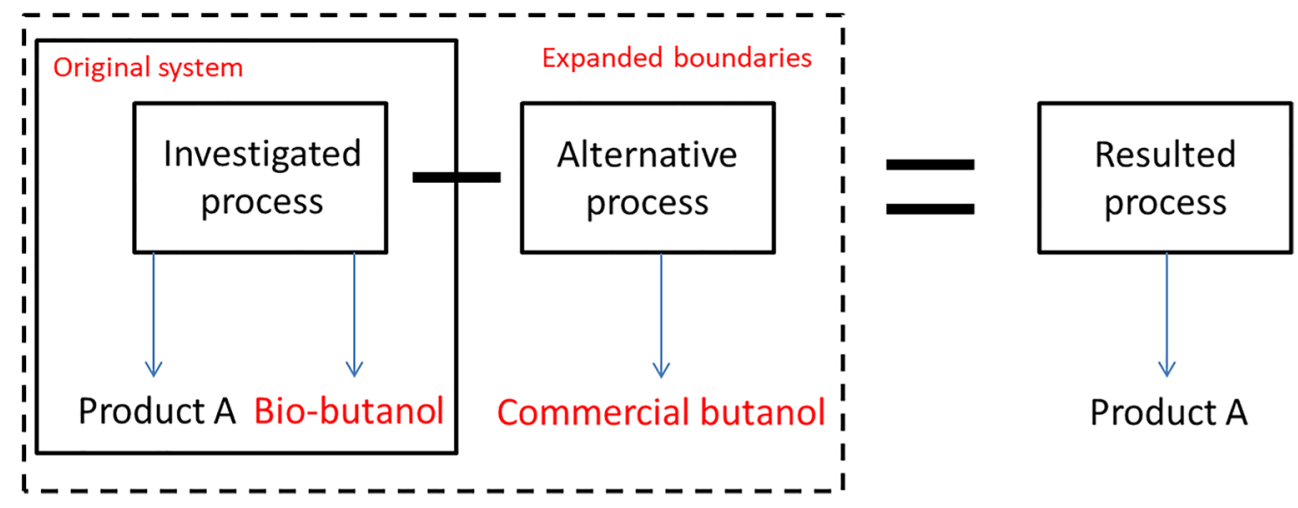

Product $\mathrm{A}$ 
Product A and bio-butanol. Bio-butanol is considered the coproduct and it is assumed to replace commercial butanol. The emissions of commercial butanol are then subtracted from the emissions produced by the system under study.

A review by Muench and Guenther (Muench and Guenther 2013) shows that the use of system expansion, also in the form of substitution, is the most common approach currently used in solving multifunctionality. The authors stated that "a frequently observed characteristic of bioenergy systems is the yield of multiple products" (Muench and Guenther 2013, p8), such as thermal energy, digestate and/or ash. However, apart from co-production processes, waste treatment and recycling require to be allocated as well. Table 1 presents an overview of 16 waste bioenergy studies that performed substitution on waste treatment processes. Fifteen out of 16 studies considered here focused on waste feedstock for energy generation, from which 8 studies concern manure, and selected an energy unit as the functional unit. On the other hand, only two studies (Negro et al. 2017; Li et al. 2018) selected a mass unit as the functional unit. In addition, 4 out of the 16 studies explicitly stated the use of attributional ELCA (Boulamanti et al. 2013; Agostini et al. 2015; Giuntoli et al. 2015, 2016) but all 16 studies conducted the ELCA in a consequential manner. The authors decided to modify the waste management practice of the original system, modelling an alternative end-use of the investigated waste feedstock. The avoided impact of the avoided management practice was then included in the original system as avoided emissions. Last, 4 studies (Bachmaier et al. 2010; Lansche and Müller 2012; Meyer-Aurich et al. 2012; Negro et al. 2017) not only substituted emissions due to the avoided manure storage, but also included the avoided production of fertilizer due to the digestate use. In this way, researchers accounted for avoided waste management and the avoided function of the waste management.

Table 1 Overview of reviewed bioenergy ELCA studies with avoided $\mathrm{CO}_{2}$-eq emissions

\begin{tabular}{|c|c|c|c|c|c|}
\hline Study & Biomass & $\begin{array}{l}\text { Type of avoided emission } \\
\text { due to substitution }\end{array}$ & $\begin{array}{l}\text { Percentage of } \\
\text { GWP result } \\
(\%)\end{array}$ & $\begin{array}{l}\text { Reference energy } \\
\text { system }\end{array}$ & $\begin{array}{l}\text { Mentioned LCA } \\
\text { approach }\end{array}$ \\
\hline (Cappelli et al. 2015) & $\begin{array}{l}\text { Macroalgae and agricultural } \\
\text { mix feedstock }\end{array}$ & $\begin{array}{l}\text { Ammonia, hydrogen } \\
\text { sulphite, nitrous } \\
\text { oxide, methane, carbon } \\
\text { dioxide }\end{array}$ & 12 & $\begin{array}{l}\text { Fossil combined heat } \\
\text { and power (CHP) }\end{array}$ & Consequential \\
\hline $\begin{array}{l}\text { (Zhang and Mabee } \\
\text { 2016) }\end{array}$ & Low carbon fuels ${ }^{b}$ & Methane, carbon dioxide & $12-50$ & $\begin{array}{l}\text { Natural gas (NG) } \\
\text { CHP }\end{array}$ & n.d. \\
\hline $\begin{array}{l}\text { (Lansche and Müller } \\
\text { 2012) }\end{array}$ & Animal manure & Methane & 50 & $\begin{array}{l}\text { German electricity } \\
\operatorname{mix}\end{array}$ & n.d. \\
\hline (Bachmaier et al. 2010) & Animal waste & Methane & $5-10$ & $\begin{array}{l}\mathrm{NG} \text { and coal } \\
\text { electricity }\end{array}$ & n.d. \\
\hline $\begin{array}{l}\text { (Meyer-Aurich et al. } \\
\text { 2012) }\end{array}$ & Corn residues and manure & Nitrous oxide and methane & $25-30$ & NG CHP & n.d. \\
\hline (Panepinto et al. 2013) & $\begin{array}{l}\text { Animal manure and } \\
\text { energy crops }\end{array}$ & Methane & $5-30$ & NG or gas oil heating & n.d. \\
\hline (Giuntoli et al. 2016) & Residual biomass & Nitrous oxide & Not shown & EU-27 electricity mix & Attributional \\
\hline (Li et al. 2018) & Dairy manure & Methane & $5-10$ & None & n.d. \\
\hline (Giuntoli et al. 2015) & Forest logging residues & Carbon dioxide & Not shown & NG heating & Attributional \\
\hline (Agostini et al. 2015) & $\begin{array}{l}\text { Animal manure and energy } \\
\text { crops }\end{array}$ & Methane & $50-65$ & Italian electricity mix & Attributional \\
\hline (Restrepo et al. 2016) & Bamboo boards & Methane & 65 & None & n.d. \\
\hline (Ruiz et al. 2018) & Biowaste $^{c}$ & Methane & 60 & None & n.d. \\
\hline (Negro et al. 2017) & Orange peel waste & Methane & $5-10$ & $\begin{array}{l}\text { Various energy } \\
\text { carriers }\end{array}$ & Consequential \\
\hline $\begin{array}{l}\text { (Lansche and Müller } \\
\text { 2017) }\end{array}$ & Fresh dung & Methane & 30 & Dung (bio-) heating & Consequential \\
\hline (Bacenetti et al. 2013) & Animal manure & Methane & $5-40$ & Italian electricity mix & n.d. \\
\hline $\begin{array}{l}\text { (Boulamanti et al. } \\
\text { 2013) }\end{array}$ & Animal manure & $\begin{array}{l}\text { Ammonia, nitrous } \\
\text { oxide and methane }\end{array}$ & 100 & EU-27 electricity mix & Attributional \\
\hline
\end{tabular}

${ }^{\text {a }}$ Agricultural feedstock mix consists of poultry manure, oil mill waste waters and citrus pulp

${ }^{\mathrm{b}}$ Low carbon fuels consist of including construction and demolition (C\&D) wood wastes, asphalt shingles, railway ties and plastics

${ }^{\mathrm{c}}$ Biowaste consists of pig slurry, cow slurry, sewage sludge and agri-food waste 


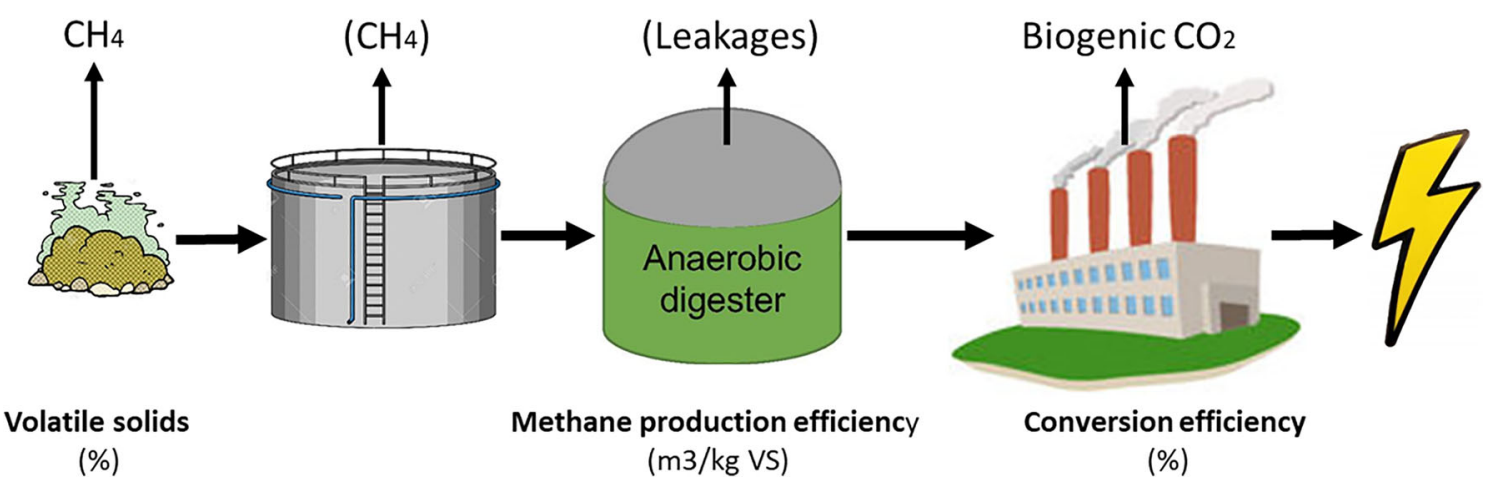

Fig. 2 Simplified system boundaries of manure ELCA studies, showing the stages which affect the GWP score. Methane from storage tanks and leakage from digesters are shown but they are potential emissions

\section{Impacts of substitution in waste treatment processes}

Waste bioenergy studies have applied substitution in waste treatment processes, leading to accounting for avoided emissions. Consequently, these avoided emissions contributed to the GWP results from as low as $5 \%$ to even $100 \%$, and in certain studies (Bachmaier et al. 2010; Lansche and Müller 2012; Boulamanti et al. 2013; Cappelli et al. 2015; Agostini et al. 2015) negative GWP results are presented due to avoided emissions. All these studies concerned animal waste; therefore, this is in contradiction with the ILCD handbook statement: "substitution, in rare cases, can lead to even negative overall environmental impacts of the analysed systems" (Wolf et al. 2010, p. 93). The extent to which avoided emissions affected the GWP depends primarily on emissions other than $\mathrm{CO}_{2}$, since studies in Table 1 concern biomass feedstock and biogenic $\mathrm{CO}_{2}$ is not regarded as GHG. Figure 2 illustrates, except from avoided emissions during spreading (i.e. avoided waste management practice), processes which contribute to GWP results highly, such as open/close storage of manure, methane production efficiency of the anaerobic digestion (AD) and conversion efficiency will affect the GWP results. Regarding avoided emissions, the main GWP contributor is the avoided methane as it is one order magnitude stronger in GHG than $\mathrm{CO}_{2}$ and is a gas produced in large quantities in avoided waste management practices.

Applying substitution in waste treatment processes can have a major effect on GWP results also due to the technical aspects of the compared systems. Therefore, if an ELCA practitioner aims at comparing the GWP of two technological systems which replace waste management practices, different values of avoided emissions may be credited to each technological system when the function of the system is not waste

Table 2 Factors affecting energy carrier production of anaerobic digestion plants of Table 1

\begin{tabular}{|c|c|c|c|c|c|c|}
\hline Study & $\begin{array}{l}\text { Methane production } \\
\text { efficiency in AD } \\
\left(\mathrm{m}^{3} / \mathrm{kg} \text { volatile solids) }\right.\end{array}$ & $\begin{array}{l}\text { Methane LHV } \\
\left(\mathrm{MJ} / \mathrm{m}^{3}\right)\end{array}$ & $\begin{array}{l}\text { Conversion } \\
\text { efficiency }(\%)\end{array}$ & $\begin{array}{l}\text { Energy carrier } \\
\text { production }(\mathrm{kWh} / \\
\text { kg volatile solids) }\end{array}$ & $\begin{array}{l}\mathrm{GWP}\left(\mathrm{g} \mathrm{CO}_{2} /\right. \\
\text { functional unit) }\end{array}$ & $\begin{array}{l}\text { Functional unit } \\
\text { (source of } \\
\text { functional unit) }\end{array}$ \\
\hline (Agostini et al. 2015) & 0.22 & 36 & 0.32 & 0.702 & -2430 & $\mathrm{kWh}$ (electricity) \\
\hline (Bacenetti et al. 2013) & 0.45 & 23.8 & 0.357 & 1.060 & -910 & $\mathrm{kWh}$ (electricity) \\
\hline (Bachmaier et al. 2010) & n.d. & n.d. & n.d. & n.d. & -910 & $\mathrm{kWh}$ (electricity) \\
\hline (Boulamanti et al. 2013) & 0.165 & 33.4 & 0.36 & 0.550 & -1195 & $\mathrm{kWh}$ (electricity) \\
\hline (Cappelli et al. 2015) & 0.37 & n.d. & n.d. & 0.525 & -0.01 & $\begin{array}{l}1.02 \mathrm{kWh} \text { (electricity), } \\
10.92 \mathrm{MJ} \text { (heat), } 1.86 \mathrm{~kg} \\
\text { of compost }\end{array}$ \\
\hline (Giuntoli et al. 2016) & 0.2 & 35.9 & $0.36^{\mathrm{a}}$ & 0.716 & n.d. & $\mathrm{kWh}$ (electricity) \\
\hline (Meyer-Aurich et al. 2012) & $0.345^{\mathrm{b}}$ & $36^{\mathrm{a}}$ & 0.38 & 1.307 & 110 & $\mathrm{kWh}$ (electricity) \\
\hline (Lansche and Müller 2012) & 0.38 & $36^{\mathrm{a}}$ & 0.36 & 1.364 & -722 & MJ (biogas) \\
\hline (Lansche and Müller 2017) & 0.15 & $36^{\mathrm{a}}$ & 0.574 & 0.859 & -1841 & MJ (heat) \\
\hline (Panepinto et al. 2013) & $0.21^{\mathrm{b}}$ & $36^{\mathrm{a}}$ & 0.40 & 0.835 & -209 & n.d. \\
\hline (Ruiz et al. 2018) & n.d. & n.d. & 0.38 & n.d. & -7 & $\mathrm{kWh}$ (electricity and heat) \\
\hline
\end{tabular}

${ }^{\mathrm{a}}$ This value was not stated, so it was assumed by the authors to perform the calculations

${ }^{\mathrm{b}}$ Only the biogas production efficiency was presented, so it was assumed that $60 \%$ consists of methane 
Fig. 3 Illustrated hypothetical example of the effect of avoided emissions on waste bioenergy systems $(\mathbf{a}, \mathbf{b})$ when compared with the reference electricity system (c)

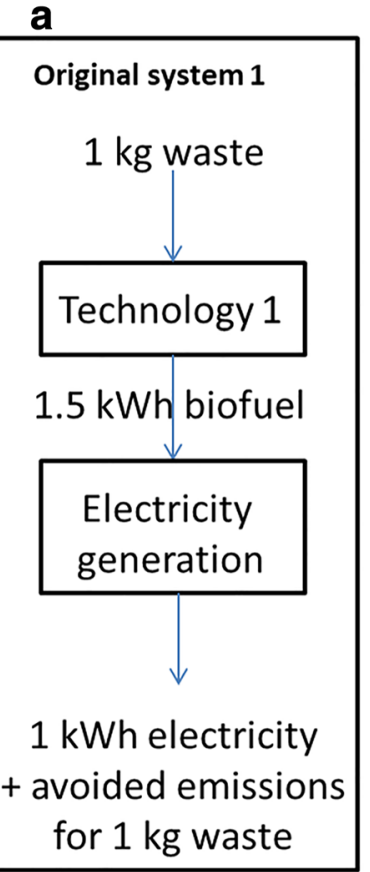

treatment. These two technological systems can both regard AD plants with different efficiencies or two different technologies which produce methane, such as $\mathrm{AD}$ and supercritical water gasification. Table 2 shows an overview of how the methane production efficiency and the conversion efficiency in various $A D$ plants with a gas engine can affect the GWP results. A lower methane production efficiency and/or conversion efficiency will result in larger amounts of feedstock needed for the AD plant in order to produce 1 functional unit $(\mathrm{kWh})$, and subsequently higher credits of avoided waste management practices.

Similarly, when comparing different waste conversion technologies with a product-related functional unit (methane or electricity/heat), credits of avoided waste management practices will benefit more the less efficient a technology is, as it requires more waste input to produce the same amount of product, as it is illustrated in a hypothetical example in Fig. 3. If one models technology 2 in Fig. $3 b$ with consequential ELCA, selects $1 \mathrm{kWh}$ of electricity as functional unit and performs substitution at the avoided waste management process, then not optimizing technology 2 would result in higher credits and possibly "improved" environmental performance. In fact, a similar result would be obtained if multifunctionality (in Fig. 3) was treated with partitioning. A higher amount of managed waste input would result in a larger share of environmental burden for the system upstream the waste bioenergy system in Fig. 3b than Fig. 3a. Nevertheless, in waste bioenergy ELCA studies, the credits (due to substitution) will have a greater effect than partitioning factors due to "avoiding" a strong GHG (methane). The paradox in this multifunctionality handling is that the functionality of the

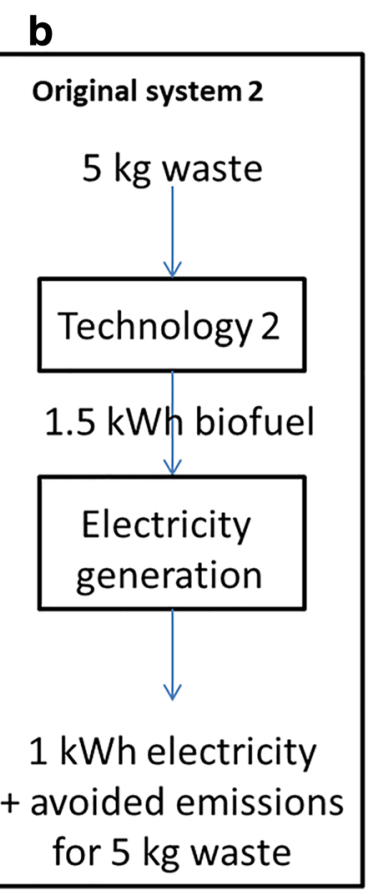

C

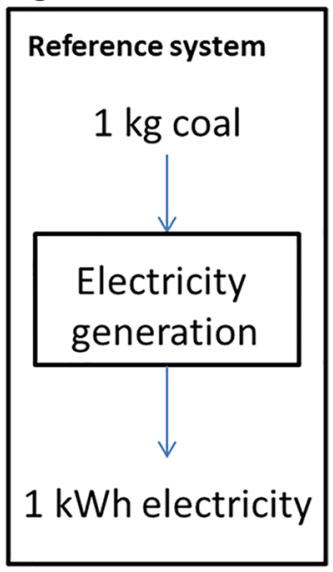

modified waste treatment system under study is not treating waste anymore, but rather generating a product such as electricity. The former uses a functional unit of input of treated waste, whereas the latter uses a functional unit of output of electricity generated. Using a functional unit of input of treated waste would not result in extra (substitution) credits due to low output conversion efficiency.

\section{Conclusions}

The use of avoided emissions in carbon accounting in ELCA of waste bioenergy studies has started to emerge as common practice. This paper aims at starting a discussion on the application of substitution in consequential ELCA studies. This is critical due to the role that second-generation biomass will have on the $1.5^{\circ} \mathrm{C}$ mitigation target. Based on literature, we showed a specific way of handling allocation and when it is used in waste bioenergy studies: the substitution method. Substitution has been mainly used for avoided waste management practices and the most common avoided gas was methane. However, we argue that the functionality of the system is crucial when applying the substitution method in processes that contribute highly to environmental impact indicators, as it can result in overestimating GHG emissions. In this way, a less energy-efficient technology might be selected from policymakers due to GHG emissions benefits instead of a more efficient technology. This paradox is originated to the change in the functionality of the original system, as avoided emissions derive from a waste management system and credit an electricity generation system. We recommend that 
practitioners should be careful when selecting the functionality of waste treatment ELCA systems and applying substitution to avoid over-accreditation, as the way substitution is used in public policy can have major implications.

Acknowledgements This work is part of the activities carried out in the framework of the H2020 European project "Zero Brine"-project no 730390. The authors would like to thank Prof. Dr. Ir. Andrea Ramirez Ramirez (Faculty of Technology, Policy and Management, Delft University of Technology) and Dr. Ir. Jeroen B. Guinée (Institute of Environmental Sciences, Leiden University) for helping to refine the aim of this work, Elena de Santo for English proofreading and the unknown reviewer for the interesting perspective he shared on substitution and functional unit effects.

Open Access This article is distributed under the terms of the Creative Commons Attribution 4.0 International License (http:// creativecommons.org/licenses/by/4.0/), which permits unrestricted use, distribution, and reproduction in any medium, provided you give appropriate credit to the original author(s) and the source, provide a link to the Creative Commons license, and indicate if changes were made.

\section{References}

Agostini A, Battini F, Giuntoli J, Tabaglio V, Padella M, Baxter D, Marelli L, Amaducci S (2015) Environmentally sustainable biogas? The key role of manure co-digestion with energy crops. Energies 8: 5234-5265. https://doi.org/10.3390/en8065234

Bacenetti J, Negri M, Fiala M, González-García S (2013) Anaerobic digestion of different feedstocks: impact on energetic and environmental balances of biogas process. Sci Total Environ 463-464:541551. https://doi.org/10.1016/j.scitotenv.2013.06.058

Bachmaier J, Effenberger M, Gronauer A (2010) Greenhouse gas balance and resource demand of biogas plants in agriculture. Eng Life Sci 10:560-569. https://doi.org/10.1002/elsc.201000073

Boulamanti AK, Donida Maglio S, Giuntoli J, Agostini A (2013) Influence of different practices on biogas sustainability. Biomass Bioenergy 53:149-161. https://doi.org/10.1016/j.biombioe.2013. 02.020

Brander M, Wylie C (2011) The use of substitution in attributional life cycle assessment. Greenh Gas Meas Manag 1:161-166. https://doi. org/10.1080/20430779.2011.637670

Cappelli A, Gigli E, Romagnoli F, Simoni S, Blumberga D, Palerno M, Guerriero E (2015) Co-digestion of macroalgae for biogas production: an LCA-based environmental evaluation. Energy Procedia 72: 3-10. https://doi.org/10.1016/j.egypro.2015.06.002

Chakravorty U, Hubert M-H, Nøstbakken L (2009) Fuel versus food. Annu Rev Resour Econ 1:645-663. https://doi.org/10.1146/ annurev.resource.050708.144200

European Commission (2010) Report from the Commission to the Council and the European Parliament on sustainability requirements for the use of solid and gaseous biomass sources in electricity, heating and cooling SEC(2010) 65 final SEC(2010) 66 final, Brussels

European Commission (2009) DIRECTIVE 2009/28/EC OF THE EUROPEAN PARLIAMENT AND OF THE COUNCIL of 23 April 2009 on the promotion of the use of energy from renewable sources and amending and subsequently repealing Directives 2001/77/EC and 2003/30/EC

Finnveden G, Hauschild MZ, Ekvall T, Guinée J, Heijungs R, Hellweg S, Koehler A, Pennington D, Suh S (2009) Recent developments in
Life Cycle Assessment. J Environ Manag 91:1-21. https://doi.org/ 10.1016/j.jenvman.2009.06.018

Giuntoli J, Agostini A, Caserini S, Lugato E, Baxter D, Marelli L (2016) Climate change impacts of power generation from residual biomass. Biomass Bioenergy 89:146-158. https://doi.org/10.1016/j. biombioe.2016.02.024

Giuntoli J, Caserini S, Marelli L, Baxter D, Agostini A (2015) Domestic heating from forest logging residues: environmental risks and benefits. J Clean Prod 99:206-216. https://doi.org/10.1016/j.jclepro. 2015.03.025

Guinee JB (2002) Handbook on life cycle assessment operational guide to the ISO standards. Int J Life Cycle Assess 7:311-313. https://doi. org/10.1007/BF02978897

Heijungs R (1997) Economic drama and the environmental stage. In: Economic drama and the environmental stage : formal derivation of algorithmic tools for environmental analysis and decision-support from a unified epistemological principle. Article / Letter to editor

Heijungs R, Guinée JB (2007) Allocation and 'what-if' scenarios in life cycle assessment of waste management systems. Waste Manag 27: 997-1005. https://doi.org/10.1016/j.wasman.2007.02.013

International Organization for Standardization (ISO) (2006a) ISO 14040: environmental management - life cycle assessment - principles and framework, Geneva

International Organization for Standardization (ISO) (2006b) ISO 14044: 2006. Environmental management-Life cycle assessmentRequirements and guidelines, 1st edn. Geneva, Switzerland

IPCC (2018) Summary for policymakers. In: Global warming of $1.5^{\circ} \mathrm{C}$. an IPCC special report on the impacts of global warming of $1.5^{\circ} \mathrm{C}$ above pre-industrial levels and related global greenhouse gas emission pathways, in the context of strengthening the global response to the threat of climate change, sustainable development, and efforts to eradicate poverty (Masson-Delmotte V, Zhai P, Pörtner H-O, Roberts D, Skea J, Shukla PR, Pirani A, Moufouma-Okia, Péan C, Pidcock R, Connors S, Matthews JBR, Chen Y, Zhou X, Gomis MI, Lonnoy E, Maycock, Tignor M, Waterfield T (eds.)). World Meteorological Organization, Geneva, Switzerland

Koffler C, Finkbeiner M (2018) Are we still keeping it "real"? Proposing a revised paradigm for recycling credits in attributional life cycle assessment. Int J Life Cycle Assess 23:181-190. https://doi.org/10. 1007/s11367-017-1404-x

Lansche J, Müller J (2017) Life cycle assessment (LCA) of biogas versus dung combustion household cooking systems in developing countries - a case study in Ethiopia. J Clean Prod 165:828-835. https:// doi.org/10.1016/j.jclepro.2017.07.116

Lansche J, Müller J (2012) Life cycle assessment of energy generation of biogas fed combined heat and power plants: environmental impact of different agricultural substrates. Eng Life Sci 12:313-320. https:// doi.org/10.1002/elsc.201100061

Li Y, Manandhar A, Li G, Shah A (2018) Life cycle assessment of integrated solid state anaerobic digestion and composting for on-farm organic residues treatment. Waste Manag 76:294-305. https://doi. org/10.1016/j.wasman.2018.03.025

Majeau-Bettez G, Dandres T, Pauliuk S, Wood R, Hertwich E, Samson R, Strømman AH (2018) Choice of allocations and constructs for attributional or consequential life cycle assessment and input-output analysis. J Ind Ecol 22:656-670. https://doi.org/10.1111/jiec.12604

Meyer-Aurich A, Schattauer A, Hellebrand HJ, Klauss H, Plöchl M, Berg W (2012) Impact of uncertainties on greenhouse gas mitigation potential of biogas production from agricultural resources. Renew Energy 37:277-284. https://doi.org/10.1016/j.renene.2011.06.030

Muench S, Guenther E (2013) A systematic review of bioenergy life cycle assessments. Appl Energy 112:257-273. https://doi.org/10. 1016/j.apenergy.2013.06.001

Negro V, Ruggeri B, Fino D, Tonini D (2017) Life cycle assessment of orange peel waste management. Resour Conserv Recycl 127:148 158. https://doi.org/10.1016/j.resconrec.2017.08.014 
Pandiyan K, Singh A, Singh S, Saxena AK, Nain L (2019) Technological interventions for utilization of crop residues and weedy biomass for second generation bio-ethanol production. Renew Energy 132:723741. https://doi.org/10.1016/j.renene.2018.08.049

Panepinto D, Genon G, Brizio E, Russolillo D (2013) Production of green energy from co-digestion: perspectives for the province of Cuneo, energetic balance and environmental sustainability. Clean Techn Environ Policy 15:1055-1062. https://doi.org/10.1007/s10098012-0568-0

Popp J, Lakner Z, Harangi-Rákos M, Fári M (2014) The effect of bioenergy expansion: food, energy, and environment. Renew Sust Energ Rev 32:559-578. https://doi.org/10.1016/j.rser.2014.01.056

Restrepo A, Becerra R, Tibaquirá JEG (2016) Energetic and carbon footprint analysis in manufacturing process of bamboo boards in Colombia. J Clean Prod 126:563-571. https://doi.org/10.1016/j. jclepro.2016.02.144

Ruiz D, San M, Corona B et al (2018) Environmental and economic analysis of power generation in a thermophilic biogas plant. Sci
Total Environ 633:1418-1428. https://doi.org/10.1016/j.scitotenv. 2018.03.169

Sandén BA, Karlström M (2007) Positive and negative feedback in consequential life-cycle assessment. J Clean Prod 15:1469-1481. https://doi.org/10.1016/j.jclepro.2006.03.005

UNEP, SETAC (2011) Global guidance principles for life cycle assessment databases

Wolf M-A, Chomkhamsri K, Brandao M, et al (2010) ILCD handbook general guide for life cycle assessment - detailed guidance

Zhang L, Mabee WE (2016) Comparative study on the life-cycle greenhouse gas emissions of the utilization of potential low carbon fuels for the cement industry. J Clean Prod 122:102-112. https://doi.org/ 10.1016/j.jclepro.2016.02.019

Publisher's note Springer Nature remains neutral with regard to jurisdictional claims in published maps and institutional affiliations. 